\title{
ISOLATION AND IDENTIFICATION OF BACILLIUS SUBTILIS FROM FISH FARMS WATER AND EVALUATION OF ITS BIOREMEDIATION EFFECT AGAINST HEAVY METALS (CADMIUM AND CUPPER)
}

\author{
Nadia M. Awny1, Abd El-Gawad A. S², Azza M. Abdelrahman² and Samar S. Negm²
}

1- Botany dept., Faculty of science, Zagazig University.

2- Central Laboratory for Aquaculture Research (CLAR), Agricultural Research Center (ARC).

\begin{abstract}
High concentrations of some heavy metals (cadmium $(\mathrm{Cd})$ and cupper $(\mathrm{Cu})$ were found in industrial and sewage water that supplied El Manzala fish farms in Egypt. The metal tolerant bacterial strain Bacillius subtilis was isolated and identified morphologically and biochemically followed by 16S rRNA gene sequence analysis. The minimum inhibitory concentrations of $\mathrm{Cd}$ and $\mathrm{Cu}$ against B. subtilis that were $(6$ and 20$) \mathrm{mg} / \mathrm{l}$, respectively. In the presence of sub lethal concentrations of $\mathrm{Cd}$ and $\mathrm{Cu}$, the $B$. subtilis strain showed an obvious metal removing potential. The environmental conditions as $\mathrm{pH}$ value and incubation temperature were studied to estimate the more efficient up-taking of $\mathrm{Cd}^{+2}$ and $\mathrm{Cu}^{+2}$, ions. The maximum uptake (5 and 10) $\mathrm{mg} / \mathrm{l}$ of $\mathrm{Cd}$ and $\mathrm{Cu}$ achieved at pH7and 8 for at $(25-30)^{\circ} \mathrm{C}$, while $\mathrm{pH} 5$ and 9 and incubation temp 10 and $40^{\circ} \mathrm{C}$ showed the lowest $\mathrm{Cd}^{+2}$ and $\mathrm{Cu}^{+2}$ sorption by bacterial biomass, respectively the obtained results could be an advantage for large scale treatment of contaminated sites.
\end{abstract}

\section{Introduction}

Nowadays, pollution of aquatic environment is a serious and growing problem throughout the world, and it is a result of increasing industrial operations and commercial chemicals discharged into the aquatic environment that release alarmingly higher amounts of heavy metals into the natural environment (AlKenawy and Niema, 2015). Heavy metals such as $\mathrm{Cd}^{+2}$ and $\mathrm{Cu}^{+2}$ are potentially harmful to most aquatic organisms even in very low concentrations and have 
been reported as hazardous environmental pollutants (Kaoud and El-Dahshan, 2010). In addition, the exposure of some metals such as cadmium and cupper may cause development of reducing immunity and diseases of the kidneys, circulatory system, nervous system, and damaging of the fetal brain (Imo et al., 2014). Heavy metals are inorganic chemicals that are non- biodegradable and will not break down into harmless forms since they leave biological cycles very slowly. Therefore, due to this fact it has become extremely important to find an eco-friendly option to cleanup metal contaminated environment and consequently to preserve the health of the deteriorating environment (Golovanova, 2008). There were several eco-friendly approaches that have been attempted focusing on heavy metals removal from environment but are expensive, disruptive and less practical under natural environmental conditions. In contrast, bioremediation, a relatively young, inexpensive and socially acceptable technology involves the use of renewable resources like microbes and plants (bioremediation) to dissolve heavy metal problems (Abouzeid et al., 2009 and Oves et al., 2013).

In bioremediation process using of microorganisms not only absorb the heavy metals but also convert the highly toxic metals to the less toxic compounds through oxido-reduction processes (Naik et al., 2013). Bacteria have been reported as efficient bio-sorbents for heavy metals due to their small size and ability to grow in a wide range of environments (Ghosh et al., 2015).

\section{Material and methods}

\section{Samples collection and heavy metal determination:}

Five different water sources were collected from aquaculture farms, namely (agricultural drainage water, fresh water, industrial waste water, sewage water and mixed water that supplied by agricultural and industrial waste water. one liter of each water sample was collected in sterile glass bottle and chilled on ice for transport to the laboratory or stored in refrigerator $\left(4^{\circ} \mathrm{C}\right)$, for total bacterial count, isolation of resistance bacteria to heavy metals and detection of some heavy metals $\left(\mathrm{Cd}^{+2}\right.$ and $\left.\mathrm{Cu}^{+2}\right)$. The samples were prepared and analyzed for determination of heavy metal by atomic absorption spectrophotometer (Thermo Electron Corporation S Series AA Spectrometer, England) according to APHA (2000).

\section{Isolation of resistant bacteria to heavy metals}

Serial dilutions $\left(10^{-1}\right.$ to $\left.10^{-7}\right)$ were prepared for each water sample. Different concentration of $\mathrm{Cd}^{+2}$ and $\mathrm{Cu}^{+2}$ ions were prepared and seeded separately into the 
sterile tryptone soya agar medium using pour plating technique, then incubated at $25^{\circ} \mathrm{C}$ for $48 \mathrm{hrs}$.

\section{Identification of resistant bacteria to heavy metals}

All bacterial isolates which survived at sub lethal concentration of $\mathrm{Cd}^{+2}$ and $\mathrm{Cu}^{+2}$ ions were purified using nutrient agar pure colonies and identified according to morphological and biochemical characterizes following Bergey's Manual of Determinative Bacteriology (Holt et al., 1994).

\section{S rRNA based identification}

The partial sequencing of $16 \mathrm{~S}$ rRNA gene of the selected bacterial strain was carried out using DNA Sequencing Service, QIAamp DNA Mini Kits, Catalogue no.51304 using primer AAGTCGAGCGGACAGATGG and CCAGTTTCCAATGACCCTCCCC. The amplified product occurred as band with molecular size $595 \mathrm{bp}$.

\section{Minimum inhibitory concentration (MIC)}

Tryptic soya broth medium $(100 \mathrm{ml})$ which contained different concentrations of $\mathrm{Cd}^{+2}(0.0$, to 60.4$)$ and $\mathrm{Cu}^{+2}(0.0$, to 316.5$) \mathrm{mg} / \mathrm{l}$, were inoculated with $0.1 \mathrm{ml}$ of previously identified isolates of $B$. subtilis $(24 \mathrm{hr}$. old) in $250 \mathrm{ml}$ flask in three replicates, were incubated for $24 \mathrm{hrs}$ at $25^{\circ} \mathrm{C}$. The growth of each bacterial isolate in absence or presence of the different concentration of metal salt was measured by the spectrophotometer as optical density at $600 \mathrm{~nm}$.

\section{Effect of $\mathbf{p H}$ values}

$0.1 \mathrm{ml}$ aliquots of $24 \mathrm{~h}$ culture of $B$. subtilis were inoculated in $25 \mathrm{ml}$ test tube containing $10 \mathrm{ml}$ of tryptic soya broth medium at different buffering basal broth medium ranged from $\mathrm{pH}(5,6,7,8$ and 9$)$. The broth medium was adjusted using $\mathrm{HCl}$ and $\mathrm{NaOH}$ buffering solutions and supplemented with concentration of (5 and 10) $\mathrm{mg} / \mathrm{l}$ of $\mathrm{Cd}^{+2}$ and $\mathrm{Cu}^{+2}$, respectively then incubated at $25^{\circ} \mathrm{C}$ for $24 \mathrm{hrs}$.

\section{Effect of incubation temperature}

$0.1 \mathrm{ml}$ aliquots of $24 \mathrm{~h}$ culture $B$. subtilis suspension were inoculated in $25 \mathrm{ml}$ test tube each contained $10 \mathrm{ml}$ of tryptic soya-broth medium (at $\mathrm{pH} 7$ ) tubes was supplemented with concentration $(5$ and 10$) \mathrm{mg} / \mathrm{l}$, of $\mathrm{Cd}^{+2}$ and $\mathrm{Cu}^{+2}$ respectively, and then incubated at different temperature $(10,15,25,30,35$ and 40$){ }^{\circ} \mathrm{C}$ for 42 hrs.

\section{Statistical analysis}

Recorded data were subjected to the statistical analysis of variance by using oneway analysis of variance (ANOVA). It was performed according to Murray (1975). 


\section{Results and discussion}

The result in table (1) showed high concentration of $\mathrm{Cd}^{+2}$, and $\mathrm{Cu}^{+2}$ in industrial, sewage water different water supply of fish farms in Egypt. It is higher than permissible limit of WHO 2004 (0.003) ppm for Cd WHO (2008) (0.05) ppm for $\mathrm{Cu}^{+2}$ (table 1). This result is in agreement with Abdel-Khalek (2015) who revealed that heavy metals of $\left(\mathrm{Cd}^{+2}\right.$ and $\left.\mathrm{Cu}^{+2}\right)$ in industrial and sewage waste water higher than recommended by WHO (2004). The increase in heavy metals occurs because of increasing in industrial operations, agricultural fertilization and commercial chemicals discharged into the aquatic environment release alarmingly higher amounts of heavy metals into the natural environment (Oliveira et al., 2011; Tian et al., 2012).

Table (1): Contents of heavy metals ions in different sources of (in water) Fish farms water.

\begin{tabular}{cccccc}
\hline $\begin{array}{c}\text { Water } \\
\text { source }\end{array}$ & $\begin{array}{c}\text { Agriculture } \\
\text { Water } \\
\text { (Abbassa } \\
\text { farms) }\end{array}$ & $\begin{array}{c}\text { Agriculture } \\
\text { Water } \\
\text { (Abbassa } \\
\text { farms) }\end{array}$ & $\begin{array}{c}\text { Industrial waste } \\
\text { water } \\
\text { (EL Manzala } \\
\text { lake) }\end{array}$ & $\begin{array}{c}\text { El-Genka } \\
\text { Sewage water } \\
\text { (EL Manzala } \\
\text { lake) }\end{array}$ & $\begin{array}{c}\text { Agriculture and } \\
\text { industrial waste } \\
\text { water } \\
\text { (EL Manzala } \\
\text { lake) }\end{array}$ \\
\hline $\mathrm{Cd}^{+2}$ & $0.0009 \pm 0.003^{\mathrm{b}}$ & $0.0002 \pm 0.0011^{\mathrm{b}}$ & $0.0177 \pm 0.0035^{\mathrm{a}}$ & $0.0049 \pm 0.0003^{\mathrm{b}}$ & $0.0056 \pm 0.0006^{\mathrm{b}}$ \\
$\mathrm{Cu}^{+2}$ & $0.0450 \pm 0.0020^{\mathrm{c}}$ & $0.0037 \pm 0.0004^{\mathrm{e}}$ & $0.0944 \pm 0.0028^{\mathrm{a}}$ & $0.0842 \pm 0.0011^{\mathrm{b}}$ & $0.0253 \pm 0.0021^{\mathrm{d}}$ \\
\hline
\end{tabular}

*Mean with different letters within column differ significantly, $\mathrm{p} \leq 0.05$. 
Table (2): Morphologically and biochemical tests used for identification of selected bacteria.

\begin{tabular}{|c|c|}
\hline Characteristics & Result \\
\hline $\begin{array}{l}\text { Colony on agar } \\
\text { shape and size: } \\
\text { Margin: } \\
\text { Elevation: } \\
\text { Color: } \\
\text { Texture: }\end{array}$ & $\begin{array}{l}\text { irregular, large } \\
\text { Undulate (wavy), } \\
\text { Umbonate white, } \\
\text { dull dry or (rough) }\end{array}$ \\
\hline Gram stain & $+\mathrm{ve}$ \\
\hline Catalase test & + ve \\
\hline Voges- prokauer test & $+\mathrm{ve}$ \\
\hline Formation of indole & -ve \\
\hline O/F test & fermentative \\
\hline \multicolumn{2}{|l|}{ Acid form: } \\
\hline D-Glucose & $+\mathrm{ve}$ \\
\hline L-Arabinose & $+\mathrm{ve}$ \\
\hline D-Xylose & +ve \\
\hline D-Mannitol & $+\mathrm{ve}$ \\
\hline D-Fructose & $+\mathrm{ve}$ \\
\hline D-Maltose & $+\mathrm{ve}$ \\
\hline D-Lactose & -ve \\
\hline Sucrose & $+\mathrm{ve}$ \\
\hline Utilization of citrate & $+\mathrm{ve}$ \\
\hline Nitrate reduction test & $+\mathrm{ve}$ \\
\hline Hydrolysis of gelatin & $+\mathrm{ve}$ \\
\hline Hydrolysis of starch & +ve \\
\hline Hydrolysis of casein & $+\mathrm{ve}$ \\
\hline Production of $\mathrm{H} 2 \mathrm{~S}$ & $+\mathrm{ve}$ \\
\hline Oxidase & Variable \\
\hline Indole test & -ve \\
\hline Citrate & $+\mathrm{ve}$ \\
\hline КОH & -ve \\
\hline Urease & -ve \\
\hline Methyle red & -ve \\
\hline Motality & $+\mathrm{ve}$ \\
\hline
\end{tabular}

Estimation and identification of bacterial resistance heavy metal toxicity Thirty different bacteria isolated from the collected industrial and sewage samples were purified and preliminary identified using conventional methods. Seventeen isolates were Gram + ve and 13 isolates were Gram - ve. Screening 
the bacterial isolates for $\left(\mathrm{Cd}^{+2}\right.$ and $\left.\mathrm{Cu}^{+2}\right)$ biosorption capability revealed a highly bioactive isolate identified as Bacillus subtilis depending on biochemical characteristics (table 2).

\section{Effect of increasing concentration heavy metals on the growth of Bacillus subtilis}

From figure (2) it was observed that the growth rate of $B$. subtilis decreased by increasing $\mathrm{Cd}^{+2}$ and $\mathrm{Cu}^{+2}$ concentrations in linear relationship in tested water samples with different tolerance degrees. Minimum inhibitory concentrations of $\mathrm{Cd}^{+2}$ and $\mathrm{Cu}^{+2}$ against $B$. subtilis were (6, and 20) ppm respectively. Results are in accordance with Vijayadeep and Sastry (2014) who found that bacterial growth decreased by increasing heavy metal concentrations. Also, Oves et al. (2013) reported that while MIC of Bacillus. $S p$ was $3 \mathrm{ppm}$ for $\mathrm{Cu}^{+2}$ and $2 \mathrm{ppm}$ in case of $\mathrm{Cd}^{+2}$. Cabrera et al. (2006) stateded that heavy metals toxicity caused denaturation and inactivation of enzyme and consumption of dissolved oxygen

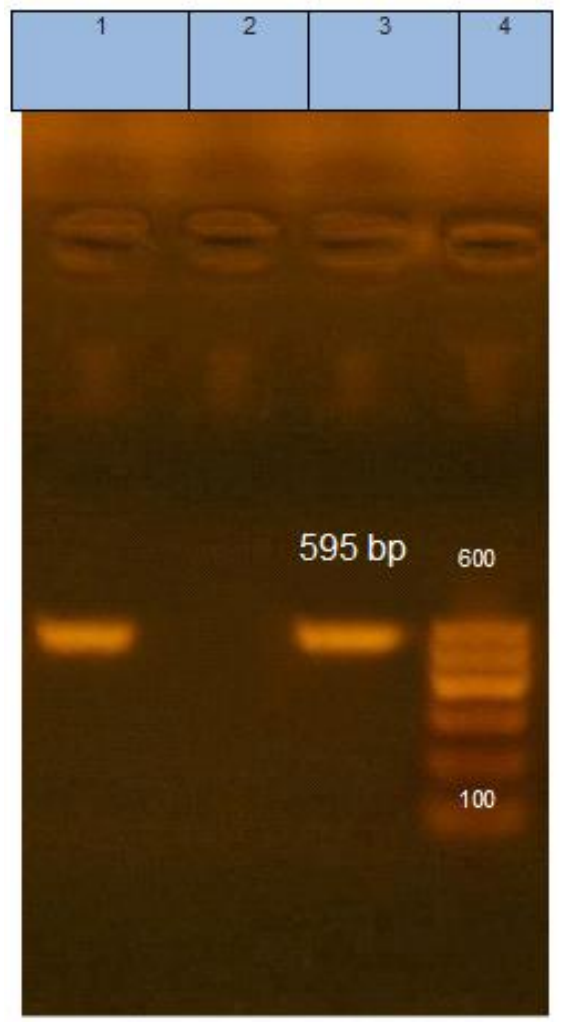

Fig. (1): Agarose gel electrophoresis showing the 16 sRNA gene amplicate of positive control (lane 1), negative control (lane 2) and tested bacteria (lane3) 500 bp DNA ladder marker in lane (4). 

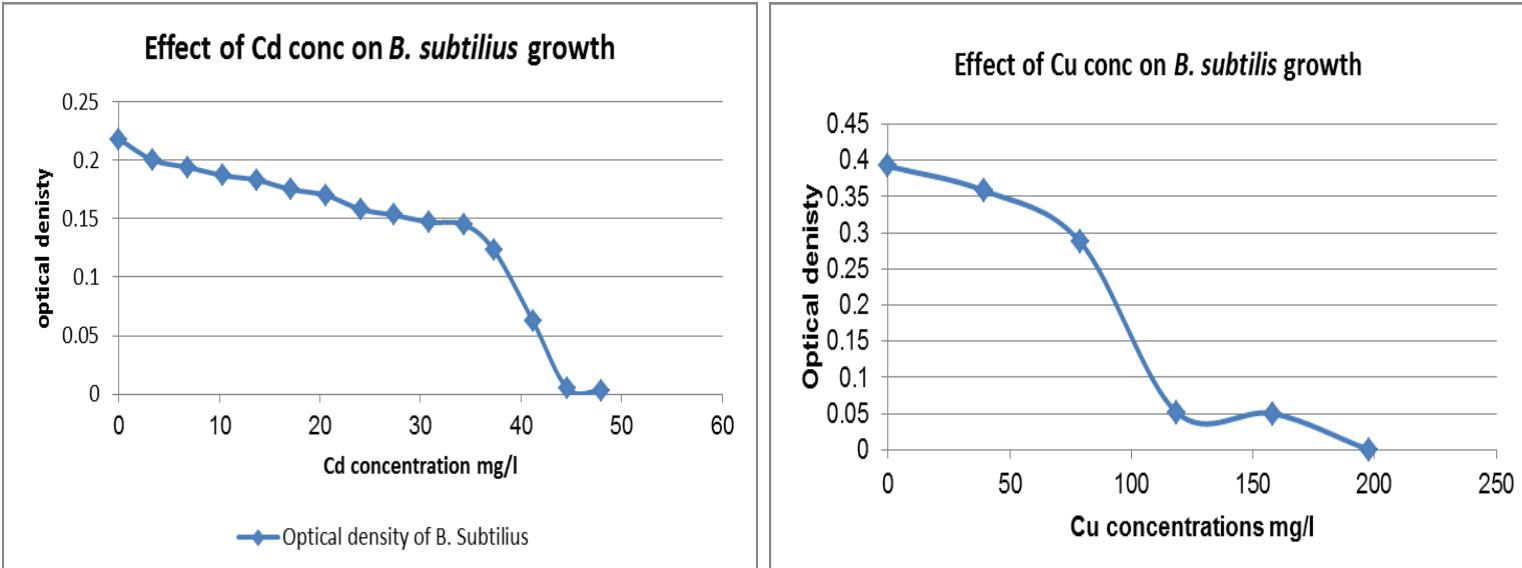

Fig (2): Effect of increasing concentration of $\mathrm{Cd}^{+2}$ and $\mathrm{Cu}^{+2}$ ions on the growth of Bacillus subtilis.

\section{Effect of environmental condition on biosorption of heavy metals}

\section{- Effect of $\mathbf{p H}$ value}

The $\mathrm{pH}$ is an important parameter, which affects the degree of ionization and the surface functional groups of the bacterial cell wall (Aryal and LiakopoulouKyriakides, 2015). Figure (3) illustrated the efficiency of $B$. subtilis to uptake (5 and 10) ppm concentration of $\mathrm{Cd}^{+2}$ and $\mathrm{Cu}^{+2}$ at $35^{\circ} \mathrm{C}$ after $24 \mathrm{~h}$. in different $\mathrm{pH}$ solution, which at $\mathrm{pH}(7$ and 8$)$ showed high growth rate of $B$. subtilis and (39.4) $\%$ of $\mathrm{Cd}^{+2}$ uptaking and (24.02) $\%$ of $\mathrm{Cu}^{+2}$ was achieved at $\mathrm{pH}$ 7. The result agreed with Oves et al., (2013) who mentioned that the optimum $\mathrm{pH}$ for $\mathrm{Cd}^{+2}$ and $\mathrm{Cu}^{+2}$ uptake was 6 by B. thuringiensis strain OSM29, and García et al. (2016) who reported that the optimum adsorption of $\mathrm{Cd}, \mathrm{Pb}, \mathrm{Cr}$ and $\mathrm{Mn}$ for the isolated strains Bacillus sp. (C13 and C16) occurred in $\mathrm{pH}$ ranges (7 to 10). In this work, the heavy metals uptake was reduced at pH 5 similar to García et al. (2016) who suggested that $\mathrm{Cd}^{+2}, \mathrm{~Pb}^{+2}, \mathrm{Cr}^{+2}$ and $\mathrm{Mn}^{+2}$ adsorption by Bacillus sp. (C13 and C16) due to increasing in $\mathrm{H}^{+}$ion concentration which changes in $\mathrm{pH}$ value effects on the solubility of the metal ions in the solution. Vázquez (2005) reported that $\mathrm{H}^{+}$ions replace some of the positive ions from the biomass surface. Also, at low $\mathrm{pH}$ values, the binding sites of the cell wall are blocked and associated with hydrogen ions that hinder the access of metal cations due to repulsive forces to the surface functional groups (Aryal and LiakopoulouKyriakides, 2015). 


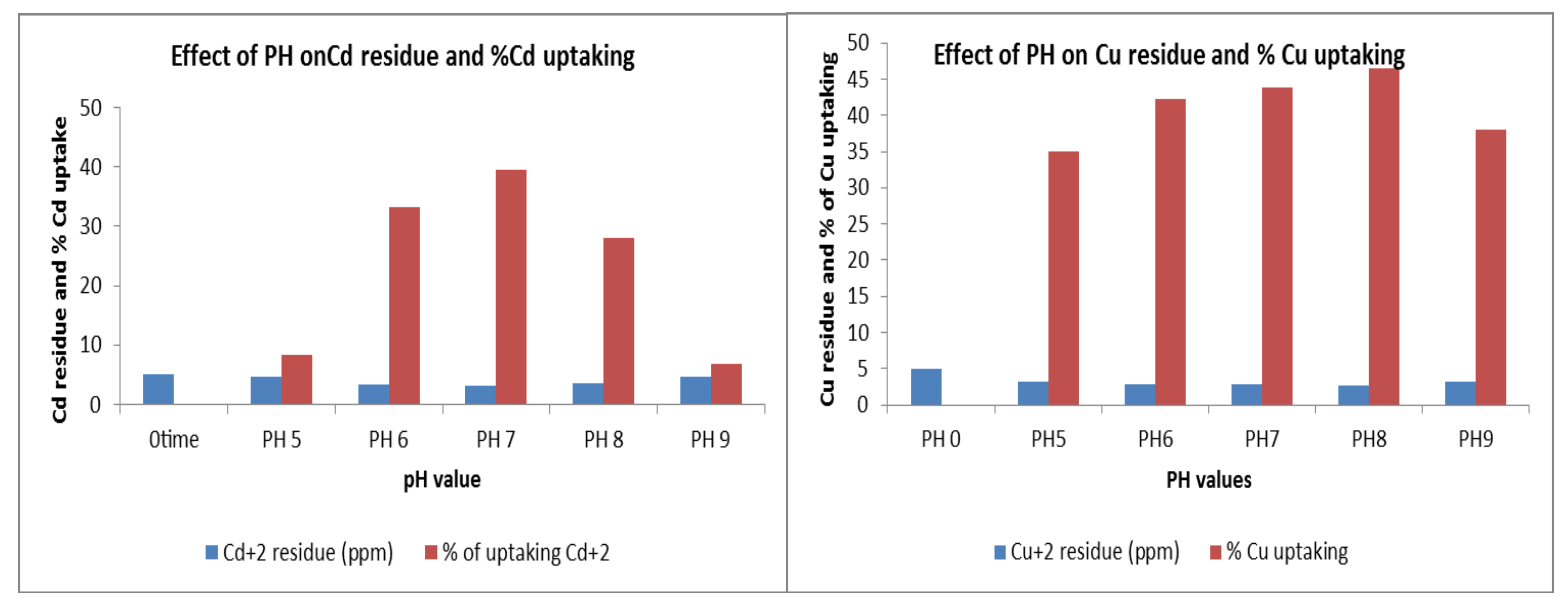

Fig (3): Uptake of $\mathrm{cd}^{+2}$ and $\mathrm{Cu}^{+2}$ ions by B. subtilis at different $\mathrm{pH}$ value

\section{Effect of temperature}

The temperature of the medium is one of the factors that effects on the sorption of metal ions (Aryal and Liakopoulou-Kyriakides 2015).

The result obtained from this work showed indicated that the optimum temperature for bioremediation of $\mathrm{Cd}^{+2}$ and $\mathrm{Cu}^{+2}$ by B. subtilis ranged from (25 to 30) (Fig 4). These results agree with most of the literature determined which the optimum temperature for heavy metal sorption between 20 and $35^{\circ} \mathrm{C}$ (Oves et al., 2013 and Veneu et al., 2013). This occurs as a result of biosorption of heavy metals that is usually modified with increase in temperature due to the increase in surface activity and kinetic energy of the solute, but destruction of some binding sites available for metal ions can occur at higher temperatures (Aryal and Liakopoulou-Kyriakides, 2013b).

However, it was noticed from our study that the growth of these bacteria and the removal capicity of heavy metal decreased at $10^{\circ} \mathrm{C}$ and $40{ }^{\circ} \mathrm{C}$. This occurs as enzyme denaturation and organisms either die or become less active (TrasarCepeda et al., 2007). García et al. (2016) study revealed that maximum remediation of $\mathrm{Cd}^{+2}, \mathrm{~Pb}^{+2}, \mathrm{Cr}^{+2}$ and $\mathrm{Mn}$ by Bacillus spp. (C13 and C16) occurred at $27 \pm 1^{\circ} \mathrm{C}$. Moreover, Mansour (2005) reported that maximum $\mathrm{Cd}^{+2}$ biosorption with $B$. circulans was attainted at $35^{\circ} \mathrm{C}$. 


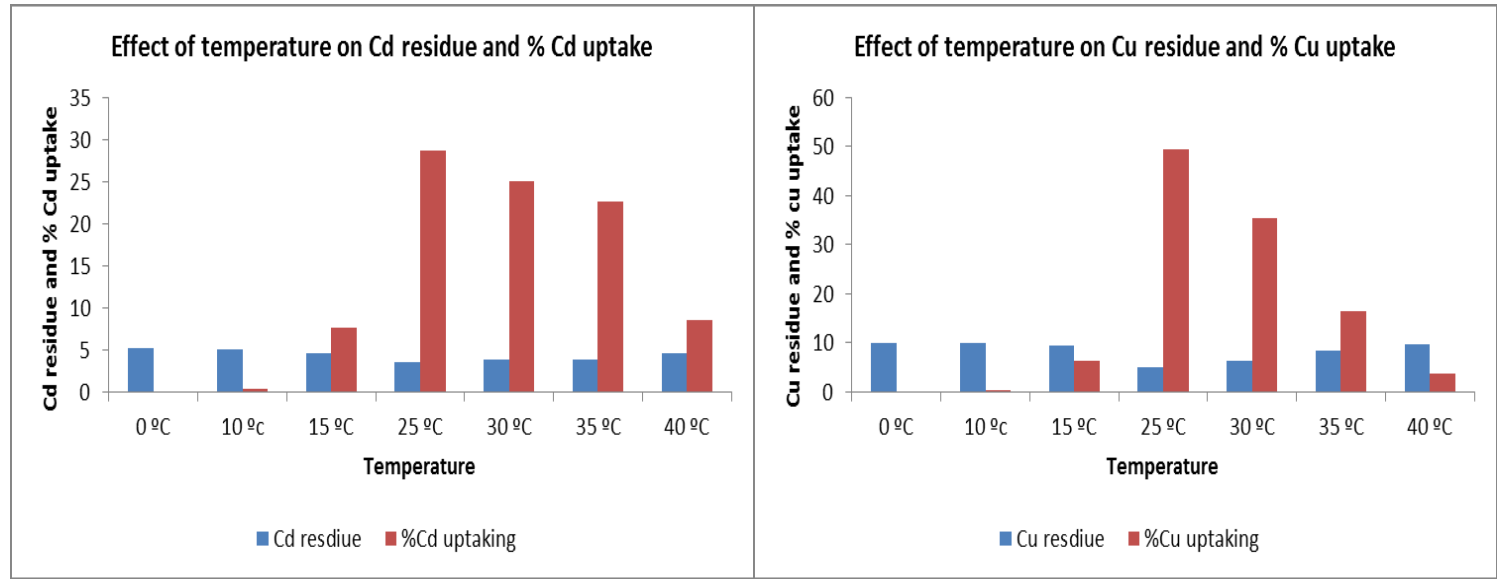

Fig (4): uptake of $\mathrm{Cd}^{+2}$ and $\mathrm{Cu}^{+2}$ ions $B$. subtilis at different temperature

\section{Conclusion}

The selected bacteria identified as Bacillus subtilis showed high resistance to heavy metal present in industrial waste water samples. The minimum inhibitory concentrations of heavy metal against strain were (6 and 20) $\mathrm{ppm}$ in case of $\mathrm{Cd}^{+2}$ and $\mathrm{Cu}^{+2}$, respectively. This isolate had capacity to remove sub lethal concentration of $\mathrm{Cd}^{+2}$ and $\mathrm{Cu}^{+2}$ ions in solution successfully. The bioremediation of heavy metal by $B$. subtilis was affected by $\mathrm{pH}$ and temperature of incubation. The maximum absorption of $\mathrm{Cd}^{+2}$ and $\mathrm{Cu}^{+2}$ by B. subtilis was at $25^{\circ} \mathrm{C}$ and $\mathrm{pH} 7$ for $\mathrm{Cd}^{+2}$ and $\mathrm{pH} 8$ for $\mathrm{Cu}^{+2}$.

\section{References}

Abdel-Khalek, A.A., (2015): Risk Assessment, Bioaccumulation of Metals and Histopathological Alterations in Nile tilapia (Oreochromis niloticus) Facing Degraded Aquatic Conditions. Bull Environ Contam Toxicol; 94: 77 - 83.

Abou- Zeid,Azza A.; Hassanein, W.A., Salama, H.M., and Fahd, G.A. (2009): Biosorption of Some Heavy Metal Ions Using Bacterial Species Isolated from Agriculture Waste Water Drains in Egypt. J. Appl. Sci. Res., 5(4):372 - 383 .

Aryal, M., and Liakopoulou-Kyriakides, M. (2013): Characterization of Mycobacterium sp. strain Spyr1 biomass and its biosorption behavior towards $\mathrm{Cr}(\mathrm{III})$ and $\mathrm{Cr}(\mathrm{VI})$ in single, binary and multi ion aqueous systems. Journal of Chemical Technology and Biotechnology, 89(4):559-568. 
Aryal, M. and Liakopoulou-Kyriakides, M. (2015): Bioremoval of heavy metals by bacterial biomass. Environ. Monit. Assess.,187(1):4173.

Al-Kenawy, D.A. and Niema A.F. Aly (2015): Levels of some heavy metals in muscles and liver of fresh water farmed fish at abbassa. Abbassa Int. J. Aqua., 8(1):20-35.

American public health association (APHA). (2000): Standard methods for the examination of water and wastewater. 16th ed., Washington, D.C., USA.

CAPMAS (2014): Egypt in figures report 2014. Central Agency for Public Mobilization and Statistics. Ref. No. 71-01112-2014.

García, R.; Campos, J.; Cruz, J.A.; Calderón, M.E.; Raynal, M.E. and Buitrón, G. (2016): Biosorption of $\mathrm{Cd}, \mathrm{Cr}, \mathrm{Mn}$, and $\mathrm{Pb}$ from aqueous solutions by Bacillus SP strain isolated from industrial waste activated sludge. TIP Revista Especializada en Ciencias Químico-Biológicas, 19(1):5-14.

Ghosh, A., Ghosh Dastidar, M., and Sreekrishnan, T.R. (2015): Recent advances in bioremediation of heavy metals and metal complex dyes. Journal of Environmental Engineering, 142(9):1-14.

Golovanova, I.L., (2008): Effects of heavy metals on the physiological and biochemical status of fishes and aquatic invertebrates. Inland Water Biology, 1(1): 93-101.

Holt, J.G.; Krieg, R.N.; Sneath, A.H.P.; Staley, T.J. and Williams, T.S. (1994): Bergey's Manual of Determinative Bacteriology. $9^{\text {th }}$ Edn. international edition.

Imo, T.; Latu, F.; Vaurasi, V.; Yoshida, J.; Amosa, P. and Sheikh, M.A. (2014): Distribution of Heavy Metals in Sediments at the Commercial and Fishing Ports in Samoa. International Journal of Environmental Science and Development, 5(6):517-521.

Kaoud, H.A and El-Dahshan A.R. (2010): Bioaccumulation and histopathological alterations of the heavy metals in Oreochromis niloticus fish Nature and Science, 8(4), 147-156.

Mansour, Seham, M. (2005): Studies on the effect of certain heavy metals on the biological activities of some microorganisms. B.Sc. Botany. Zagazig Univeristy.

Murray, R.S. (1975): Probability and statistics, McGRAW-Hill book Company. Naik, M.M. and Dubey, S. (2013): Lead resistant bacteria: Lead resistance mechanisms, their applications in lead bioremediation and biomonitoring. Ecotoxicology and Environmental Safety, 98:1-7. 
Oliveira, S.M.; Pessenda, L.C.; Gouveia, S.E. and Favaro, D.I. (2011): Heavy metal concentrations in soils from a remote oceanic island, Fernando de Noronha. Braz. An. Acad. Bras. Cienc. 83:1193-1206.

Oves, M.; Khan, M. S. and Zaidi, A. (2013): Biosorption of heavy metals by Bacillus thuringiensis strain OSM29 originating from industrial effluent contaminated north Indian soil. Saudi Journal of Biological Sciences, 20:121-129.

Tian, H.Z.; Lu, L.; Cheng, K.; Hao, J.M.; Zhao, D.; Wang, Y.; Jia, W.X. and Qiu, P.P., (2012): Anthropogenic atmospheric nickel emissions and its distribution characteristics in China. Sci. Total Environ.,417: 418-157.

Trasar-Cepeda, C.; Gil-Sotres, F. and Leiro's, M.C. (2007): Thermodynamic parameters of enzymes in grassland soils from Galicia, NW Spain. Soil Biol. Biochem., 39:311-319.

Vázquez, V.R. (2005): Bioadsorción de metals pesados en solución acuosa mediante biomasa bacteriana muerta. Tesis de Licenciatura de Biología. Departamento de Química y Biología, Escuela de Ciencias, Universidad de las Américas, Puebla, México, 1-76.

Vijayadeep, C. and Sastry, P.S. (2014): Effect of Heavy Metal Uptake by $E$. coli and Bacillus sps. Vijayadeep and Sastry. J. Bioremed. Biodeg., 5(5):1.

Veneu, D.M.; Torem, M. L. and Pino, G. A. H. (2013): Fundamental aspects of copper and zinc removal from aqueous solutions using a Streptomyces lunalinharesii strain. Minerals Engineering, 48:44-50.

World Health Organization (2004): Guidelines for drinking-water quality (Vol. 1). World Health Organization. 
عزل وتعريف سلالة باسيلس ساتليس العصوية المعزولة من مياه المزارع السمكيه وتقييم مدى معالجتها الحيويه لعنصرى الكادميوم والنحاس

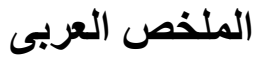

لقد وجدت تركيزات عاليه من بعض المعادن الثقيله مثل (الكادميوم والنحاس) فى مصادر المياه من الصرف الصحى و الصناعي-و التى تغذى المزارع السمكيه ببحيرة المنزله فى مصر. تم عزل وتعريف السلالة المختارة المقاومه لسميه المعادن الثقيله باستخدام SRNA 16 وتحليل التتابع الجينى على انها باسيلس ساتليس. تم تعيين اقل جرعة مثبطه من المعادن الثقيله لبكتريا باسيلس ساتليس العصويه ووجدت انها 6 مليجر ام/لتر لعنصر الكادميوم و20 مليجر ام/لترلعنصر النحاس تم استخدام جرعات نصف مميته لاختبار مدى امتصاصها بو اسطة البكتريا المقاومه لها مع در اسة الظروف البيئيه المختلفه مثل الاس الهيدروجينى واختلاف درجات الحرارة. حيث وجد ان اعلى امتصاص يحدث عند درجة حرارة 25 الى 30 درجه مئويه فى وسط متعادل و يزيد الامتصاص بزيادة الوقت بينما يحدث نمو ضعيف للسلالة البكتيرية المختبره عند درجه حرارة 10 إلى 40كما لوحظ انه عندما يكون الوسط البيئى حمضى يقل نمو البكتريا وبالتالى يقل امتصاص تللك المعادن. 